\title{
Vegetative compatibility and molecular characterization of Fusarium graminearum isolates from the State of Paraná, Brazil
}

\author{
Compatibilidade vegetativa e caracterização molecular de isolados patogênicos de Fusarium graminearum do \\ Estado do Paraná
}

\author{
Cleverson Busso ${ }^{\mathrm{I}}$ Edilson Nobuyoshi Kaneshima ${ }^{\mathrm{II}}$ Francisco de Assis Franco ${ }^{\text {III }}$ Carmen Boto Querol ${ }^{\mathrm{I}}$ \\ Marialba Avezum Alves de Castro-Prado ${ }^{\mathrm{I}}$
}

- NOTA apresentaram grande similaridade entre si. Os resultados sugerem a origem clonal dos isolados de $\mathbf{F}$. graminearum analisados.

Palavras-chave: Fusarium graminearum, grupos de compatibilidade vegetativa, RAPD, variabilidade genética.

Fusarium graminearum (teleomorphic Gibberella zeae) is the causal agent of Fusarium head blight (FHB) of wheat. Disease is an agricultural great problem, being responsible for losses yearly due to lower yield and quality of the grain. In addiction, grains infected with $\boldsymbol{F}$. graminearum contain mycotoxins that are harmful to humans and domestic animals. Most of wheat varieties are susceptible to the pathogen, and at present, no fungicides are available to control FHB efficiently (JURADO et al., 2006; MIEDANER, 1997).

Effective management of FHB, including incorporation of improved levels of resistance of cultivars and use of cultural options is needed to minimize the impact of the disease and ensure the sustainability of the crop in the region. For applying efficient FHB management strategies to augment host resistance, knowledge about the genetic diversity and structure of naturally occurring pathogen populations is crucial (BOTTALICO \& PERRONE, 2002; MIEDANER, 1997). RAPD: o grupo A, formado pelos isolados F-2 e F-9, e o grupo $B$, composto pelos demais isolados, os quais

\footnotetext{
'Departamento de Biologia Celular e Genética, Universidade Estadual de Maringá (UEM). Av. Colombo 5790, 87020-900, Maringá, PR, Brasil. E-mail: maacprado@uem.br. Autor para correspondência.

IIDepartamento de Análises Clínicas, UEM, Maringá, PR, Brasil.

II'Cooperativa Central de Pesquisa Agrícola, BR 467, Km 98 - POX 301, Cascavel, PR, Brasil.
} 
Different methods have been used to assess genetic variability in populations of phytopathogenic fungi such as RAPD analyses and vegetative compatibility grouping (VCG). High levels of genotypic diversity in populations of $\boldsymbol{F}$. graminearum, using RAPD markers, were demonstrated by DUSABENYAGASANI et al. (1999) and GILBERT et al. (2001). Vegetative compatibility phenotypes, on the other hand, are naturally occurring genetic markers which have been used to differentiate isolates of Fusarium species (BAAYEN et al., 1998; PUHALLA, 1985). VCG is regulated by multiple vegetative incompatibility loci, named vic or het, so that only compatible strains, believed to be clonally related, may produce stable heterokaryons amongst themselves and undergo parasexual recombination (KLITTICH \& LESLIE, 1988; PUHALLA, 1985).

In this study, our aim was to examine the genetic variability of Brazilian $\boldsymbol{F}$. graminearum isolates using genetic (VCG) and molecular (RAPD) methods.

Monospore isolates of $\boldsymbol{F}$. graminearum (F-1 to F-9) were obtained from wheat spikes with symptoms of head blight. Isolates had been collected on August (F-1 to F-6) and September (F-7 to F-9) of 2004, in the Experimental Farm of Coodetec (Palotina, PR, Brazil) from cultivars CD104 (F-1 and F-5), CD 105 (F-2 and F4), CD 111 (F-6), CDI 200205(F-3), CDI 200104 (F-7 and F-8) and CDI 200106 (F-9). Species, identified at the Mycology Department of the Federal University of Pernambuco in Recife, PE, Brazil, were maintained at a temperature of $5^{\circ} \mathrm{C}$. Oatmeal-Agar (OA), Minimal Medium (MM) and Complete Medium were used (CM) (PUHALLA, 1985). Mutants of $\boldsymbol{F}$. graminearum which were unable to use nitrate as a nitrogen source (nit) were obtained in $\mathrm{MM}+\mathrm{NaNO}_{3}(0.2 \%)+\mathrm{KClO}_{3}(3.0 \%)$. Mycelium plugs ( $5 \mathrm{~mm}$ ) for each nit mutant were paired in petri dishes containing $\mathrm{MM}+\mathrm{NaNO}_{3}$ for vegetative complementation tests. Plates were incubated at $24 \pm 2^{\circ} \mathrm{C}$ during 7 to 21 days and then analyzed for heterokaryon formation. Pure cultures of $\boldsymbol{F}$. graminearum were grown in CM for 4 days at $25^{\circ} \mathrm{C}$ for the genomic DNA extraction and RAPD-PCR amplification (LOUDON et al., 1993). All experiments were repeated at least twice. Primers PR2 (5’ TGCCGAGCTG3'), PR3(5' CCTTGACGCA3'), PR4(5' CAGGCCCTTC 3'), OPW2 (5' TGCCGAGCTG 3’), OPW7 (5' GAAACGGGTG 3'), OPW8 (5' GTGACGTAGG 3’), OPW9 (5'GGGTAACGCC 3’) and OPW10 (5' GTGATCGCAG 3') were used. Dendrogram was produced by cluster analysis using the unweighted pair-grouped method by arithmetic average (UPGMA).

Mutants nit from F1 to F-9 isolates were divided into three distinct phenotypic classes: nit1 (nitrate non-utilizing), Nit3 (nitrite and nitrate nonutilizing), and NitM (hypoxanthine and nitrate nonutilizing) (PUHALLA, 1985). Three distinct vegetative compatibility groupings (VCG) were identified by pairing nit mutants of F-1 to F-9 isolates in all possible combinations: VCG1 comprised isolates F-2, F-3 and F-4; VCG2 comprised isolates F-1, F-6 and F-9; VCG3 formed by F-5, F-7 and F-8 isolates. Mutants NitM of isolates F-6 and F-9 showed vegetative complementation among themselves suggesting the existence of multiple loci controlling the production of the molybdenum-containing co-factor in $\boldsymbol{F}$. graminearum, such as in Neurospora crassa and $\boldsymbol{F}$. moniliforme (KLITTICH \& LESLIE, 1988; TOMSETT \& GARRETT, 1980)

RAPD analyses were performed using eight different random primers. Figure 1 a shows an additional band (polymorphic) of approximately $2000 \mathrm{bp}$ in isolate F-2. On the other hand, isolates F-2 and F-9 showed polymorphism in relation to other isolates owing to the absence of an approximately 1300 bp band and additional band of approximately $650 \mathrm{bp}$ (Figure 1b). Isolates were separated in two RAPD groups: Group A made up of isolates F-2 and F-9, with $86.4 \%$ similarity and Group B made up of the remaining isolates (F-1, F-3, F-4, F-5, F-6, F-7 and F-8) (Figure 2). Conversely, VCG analyses separated F-2 and F-9 isolates into VCG1 and VCG2, respectively. Likewise, isolates F-1, F-3, F-4, F-5, F-6, F-7 and F-8, included in Group B using molecular markers, were separated into different VCGs. F-5 and F-6 isolates presented great genetic similarity when PCR markers were used, but could be differentiated when the VCG method was employed. Although isolates F-1, F-4, F-7 and F-8 showed 86.8\% similarity in the molecular analysis, they were located in distinct VCGs. Similar results were obtained in the characterization of $\boldsymbol{F}$. graminearum isolates from Canada. Isolates were grouped into 14 VCGs, but were contrastingly separate in only nine genetically distinct groups when analyzed by PCR (GILBERT et al., 2001).

Although only a small number of $\boldsymbol{F}$. graminearum isolates were analyzed in the present work, they were collected from a single and restricted geographic area, which had just suffered the first incidence of the Fusarium head blight. Probably exchanges of nuclear material through sexual or parasexual recombination among isolates of the same VCG, had still not occurred. This fact may justify the low genetic variability among F-1 to F-9 isolates (Figure 1). Genetic variability in populations of $\boldsymbol{G}$. zeae from two small areas in Kansas and North Dakota (USA) were identified by ZELLER et al. (2003). Whereas genetic variability was related to the occurrence of 


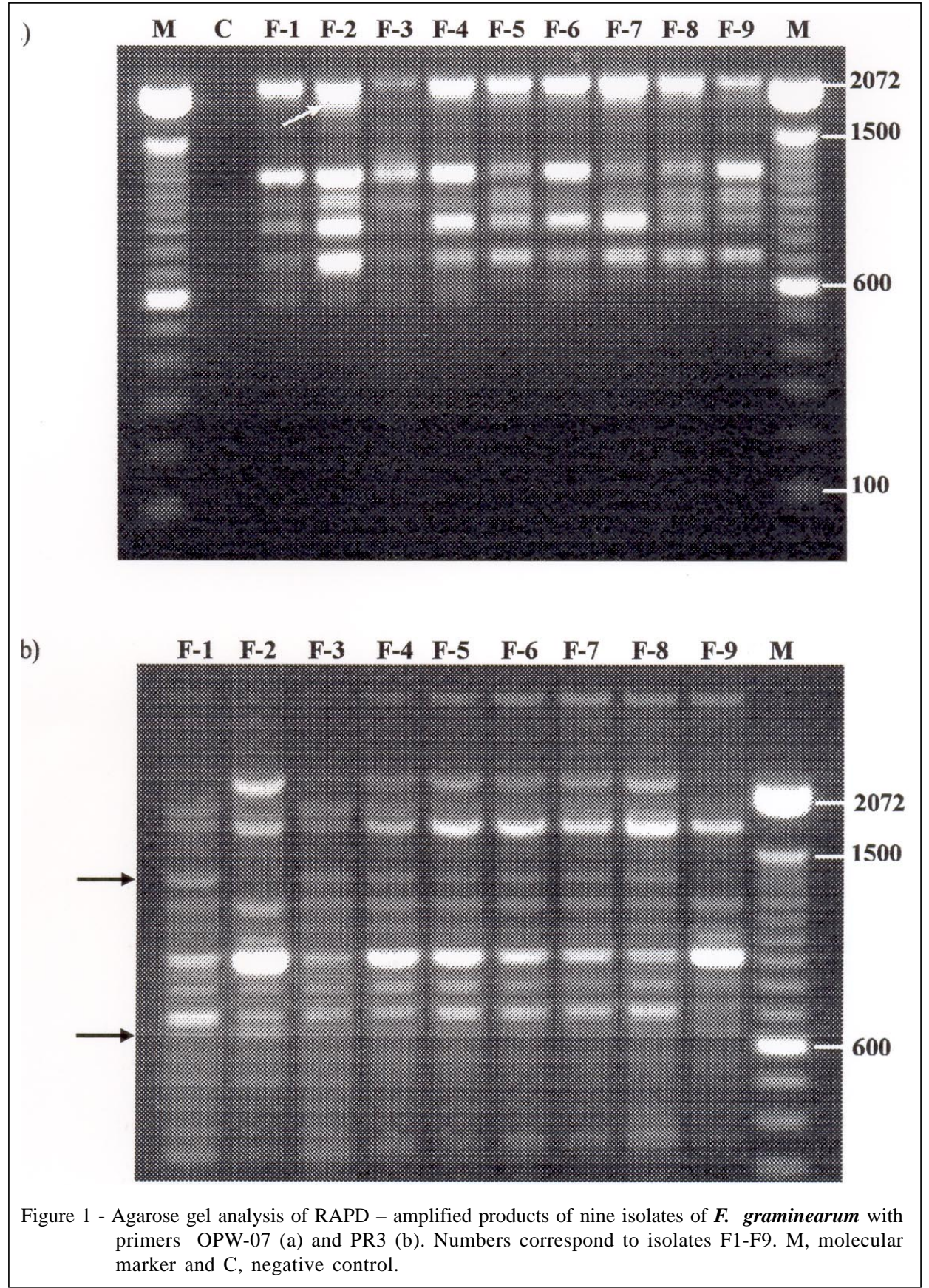

genetic recombination among the isolates, the authors suggested that both populations belonged to a single and panmitic population.

The occurrence of closely related genotypes in the same geographic area suggested that $\boldsymbol{F}$. graminearum population under analysis was fairly clonal. Other analyses involving a larger number of organisms from distinct geographical origins and harvests they should be undertaken to confirm this hypothesis.
The utilization of VCG analysis coupled to RAPD analysis indicates that $\boldsymbol{F}$. graminearum isolates are fairly similar, with three VCGs and two RAPD clusters.

\section{ACKNOWLEDGMENTS}

This research was partly supported by the Central Cooperative for Agricultural Research and by CNPq (Brazilian National Council for Scientific and Technological Development).

Ciência Rural, v.37, n.6, nov-dez, 2007. 


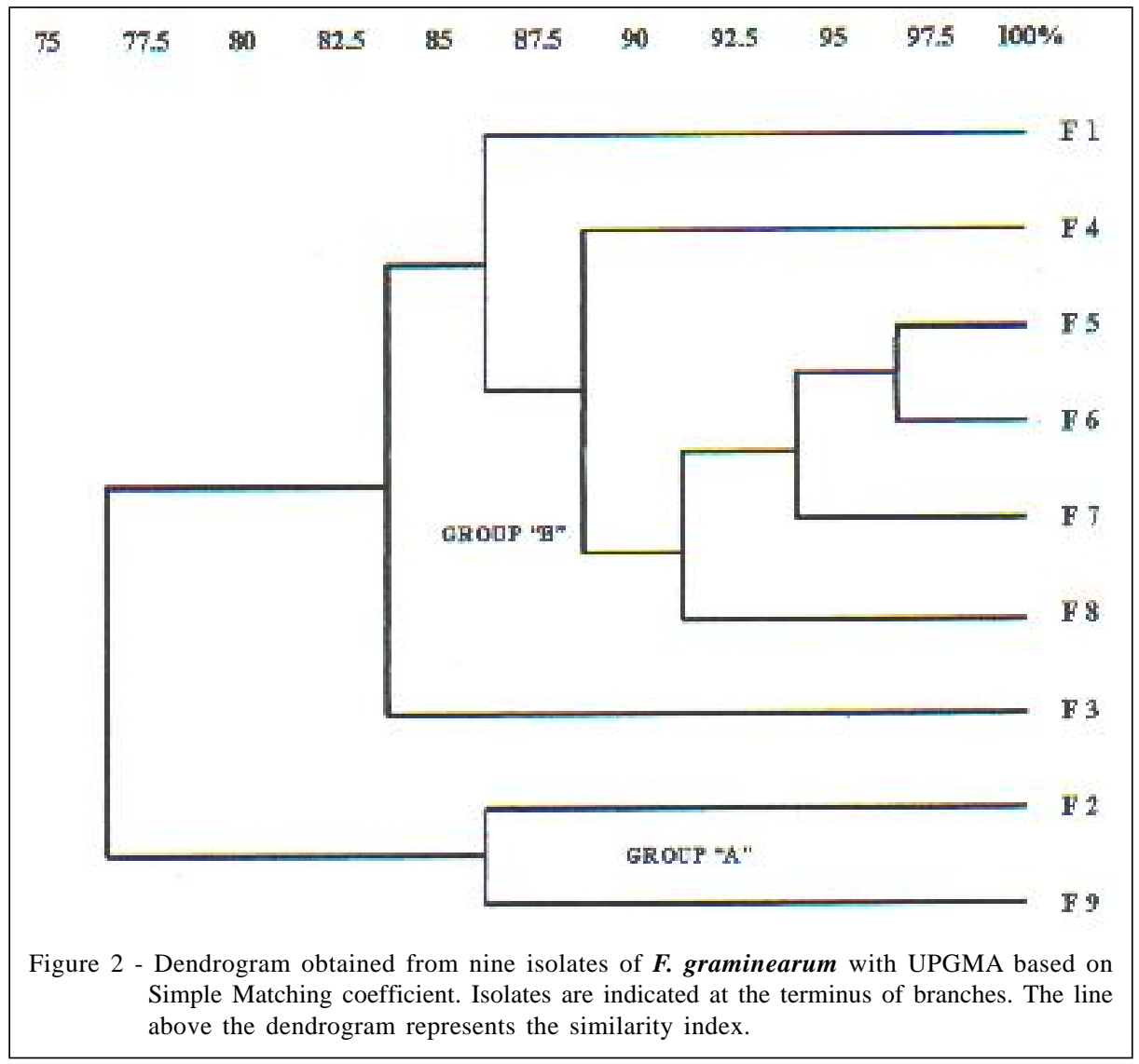

\section{REFERENCES}

BAAYEN, R.P. et al. Pathogenic, genetic and molecular characterization of Fusarium oxysporium f. sp. Lilii. European Journal Plant Pathology, v.104, p.887-894, 1998.

BOTTALICO, A.; PERRONE, G. Toxigenic Fusarium species and mycotoxins associated with head blight in small-grain cereals in Europe. European Journal Plant Pathology, v.108, p.611-624, 2002.

DUSABENYAGASANI, M. et al. Genetic diversity among Fusarium graminearum strains from Ontario and Quebec. Canadian Journal of Plant Pathology, v.21, p.308-314, 1999.

GILBERT, J. et al. Comparison of Canadian Fusarium graminearum isolates for aggressiveness, vegetative compatibility, and production of ergosterol and mycotoxins. Mycopathology, v.153, p.209-215, 2001.

JURADO, M. et al. PCR-based strategy to detect contamination with mycotoxigenic Fusarium species in maize. Systematic and Applied Microbiology, v.29, p.681-689, 2006.
KLITTICH, C.J.R.; LESLIE, J.F. Nitrate reduction mutants of Fusarium moniliforme (Gibberella fujikuroi). Genetics, v.118, p.417-423, 1988.

LOUDON, K.W. et al. Application of polymerase chain reaction to fingerprint Aspergillus fumigatus by randon amplification of polymorphic DNA. Journal Clinic Microbiology, v.31, p.1117-1121, 1993.

MIEDANER, T. Breeding wheat and rye for resistance to Fusarium diseases. Plant Breeding, v.116, p.201-220, 1997.

PUHALLA J.E. Classification of strains of Fusarium oxysporum on the basis of vegetative compatibility. Canadian Journal of Botany, v.63, p.179-183, 1985.

TOMSETT, A.B.; GARRETT, R.H. The isolation and characterization of mutants defective in nitrate assimilation in Neurospora crassa. Genetics, v.95, p.649-660, 1980.

ZELLER, K.A. et al. Diversity of epidemic populations of Gibberella zeae from quadrats in Kansas and North Dakota. Phytopathology, v.93, p.874-880, 2003. 